\title{
Postmodernizmin “Din” Sorunu
}

\section{Mustafa TEKIN*}

\section{The Problem of Religion in Postmodernity}

Citation/C: Tekin, Mustafa, (2015). The Problem of Religion in Postmodernity, Milel ve Nihal, 12 (2), 7-24.

Abstract: Modernism appeared a new imagination of a God, a universe and a human differently from a religion. Humanbeing became a new reference instead of the God; and The truth was tried to found by humanbeing on new values. Consequently hegemony of church (or God) would end. But the world witnessed bigger hegemonies and conflicts. In the meantime, modernism was criticised. At thet point, postmodernism came in to repair criticised dimensions of modernism. The truth became relatively, but postmodernism offered awards with hope on religion and liberty. Specially all of countries except in west saw postmodernism as a redemptive in this sense. We, in this article, tried to analyze the thesis of postmodernism at titles of "the truth" and "liberty/totalitarism" with the relation of religion. The relations between the God and humanbeing is a problem. It deepens crisis of humanbeing "the truth" and "liberty."

Key Words: postmodernism, religion, the truth, liberty, totalitarism.

Atıf/C: Tekin, Mustafa, (2015). Postmodernizmin "Din" Sorunu, Milel ve Nihal, $12(2), 7-24$.

Öz: Modernizm, dinden farklı olarak yeni bir Tanrı, evren ve insan tanımıyla

* Prof. Dr., İstanbul Üniversitesi, İlahiyat Fakültesi, Din Sosyolojisi Anabilim Dalı [mtekin@istanbul.edu.tr] 
ortaya çıkmıştı. Bu tasarıda Tanrı yerine insan yeni referans olurken, hakikat de insan tarafından inşa edilmeye çalışıldı. Böylece insanlık kilise hegemonyasından kurtularak özgürleşecekt. Fakat dünya daha büyük bir hegemonya ve çatışmaya şahitlik etti. Bu arada modernizm de çok ciddi eleştiriler aldı. Tam da bu noktada postmodernizm, modernizmin eleştirilen yönlerini telafi etmek üzere devreye girdi. Postmodernizm, hakikati parçalayıp göreli hale getirirken insanın tüm tutku ve arzularıyla kendisinin referansı olmaya devam etti. Böylece her bir insan, kendi başına Tanrı haline geldi. Fakat postmodernizm, sahip olduğu içeriğiyle din ve özgürlük konusunda ümit dolu vaatlerde bulundu. Özellikle batı-dışı dünya, bu anlamda postmodernizmi bir kurtarıcı olarak gördü. Bu makalede biz, "hakikat" ve özgürlük/totalitarizm" başlıkları üzerinden postmodernizmin bu tezlerini "din"le bağlantılı olarak analiz etmeye çalıştık. Kanaatimizce postmodernizmin Tanrı ve insan arasında kurduğu ilişki problemlidir. İnsanın hakikat ve özgürlük konusunda yaşadığı krizler daha da derinleşmiştir.

Anahtar Kelimeler: postmodernizm, din, hakikat, özgürlük, totalitarizm.

\section{Giriş}

Post/modern kavramı, içerikleri itibarıla "modern" kavramına özdeşlik ve farklılık açısından bir ilişki ile bağlıdır. Postmodernliğin, modernliğin bir devamı mı sayılacağı; yoksa ayrı bir süreç mi kabul edileceği noktasında tartışmalar bulunmaktadır $\mathrm{ki}^{1}$, modernizm ile postmodernizm arasındaki özdeşlik ve farklılık kavramlarını bu noktada dile getirmekteyiz. Biz ise, özü ve yönelimleri itibarıla birbirlerinin devamı olup, yöntemleri itibarıyla birbirinden farklı oldukları kanaatini taşıyoruz. Bunu ilerleyen satırlarda açmaya çalışacağız. Özellikle gerek modernlik gerekse postmodernliğin dinle ilişkisi söz konusu olduğunda, bunun tezahürlerini daha net izlemenin mümkün olacağını düşünmekteyiz.

Batı dünyasını kendi içinde bazı dönemlere ayırmak gerekirse, operasyonel olarak üç aşama düşünebiliriz. İlki, Tanrı ve vahyi bilginin merkezde olduğu Ortaçağ ya da teokratik dönem. İkincisi, Rönesans, Reform ve Aydınlanma gibi süreçlerle olgunlaşarak kendisini gösteren modern dönem; ve nihayet 20. Yüzyıl ortalarından itibaren analizlere dahil edilen postmodern dönem. Hiç şüphesiz farklı bir bakış açısından ikinci ve üçüncü dönemler birleştirilerek geleneksel ve modern dönem şeklinde bir kategorizasyon da mümkündür. Fakat biz yaklaşımımız itibarıyla postmodernliği kimi farklılıkları sebebiyle 3. dönem olarak konumlandırmaktayız.

1 Bkz. David Harvey, Postmodernliğin Durumu-Kültürel Değişimin Kökenleri, Çev.: S. Savran (İstanbul: Metis, 1999), s. 133 vd. 
Burada esas kırılma noktasını modernliğe geçiş oluşturmuştur. Zira Rönesans ile birlikte gelişen Hümanizma, Tanrı ve vahiy merkezli bir dünya ve evrenden insan merkezli bir dünya ve evrene geçişi tanımlamıştır. Böylece Tanrı ve vahiy temel referans olmaktan çıkarak, insan bir referans sistemi olarak Tanrı'nın yerine ikame olunmuştur. Bunun doğal sonucu olarak da, insanın ürettiği bilgiler vahyin yerini tutmuştur. Reformasyon süreci ile de bireyselleşme ve sekülerleşme kendisini göstermiştir. Bireyselleşme ile insan, Tanrı ile bağlarından da boşandırılmaktaydı. "Saint-Simoncular indivudailizmi, düzen, din, ortaklık ve adama umutlarıyla karşılaştırdıkları modern eleştirel dönemin bozukluklarını, onu tanrıtanımazlığın, bireyselciliğin temelini atan olumsuz düşüncelere işaret etmek için kullandılar." ${ }^{2}$ Sekülerleşme, Tanrı ile insanın otorite alanlarının yeniden düzenlenmesi ve dinin bir irtifa kaybı yaşamasına tekabül etmekteydi. Aydınlanma ise, Kant'ın "Aydınlanma nedir" sorusuna verdiği cevapta ortaya çıktığı gibi insanın kendi eliyle düşmüş olduğu ergin olmayış halinden kendi imkanlarıyla kurtulmasın ifade etmekteydi. ${ }^{3}$ Bunun anlamı; insanın hakikatin kaynağı olarak dünyayı kendisinin inşa edebileceği ve bu bağlamda Tanrı'ya ihtiyaç duymamasıydı. Dikkat edilirse, Rönesans'tan bu yana gelişen süreç, modern dünyanın hem zihni arkaplanının oluşması hem de gündelik hayat pratiklerinin üretimleri için uygun araçları sağlamasıdır.

Modernlik tüm dünya ölçeğinde tezahürlerini göstermeye başladı. İçkin bir dünya görüşüne sahip modernlik bir çok krizleriyle de eleştiri konusu oldu. Anlam sorunu ${ }^{4}$, bu krizlerin başında gelmekteydi. Fakat esasta modernizmin teori ve pratiklerinde totaliterlik vasfı sebebiyle, modernliğe duyulan inançta şüphelerin artması ve uyandırdığı büyülü hayranlığın sönmesi yeni arayışları hızlandırdı. Bilhassa I. ve II. Dünya savaşları, Avrupa'nın ortasında ortaya çıkan faşist iktidarlar, modernliğin ciddi ciddi sorgulanmasına sebep olan kriz noktaları idi. Diğer yandan modernizme dair batılılarca geliştirilen uygulamalar, Batı-dışı toplumların ciddi tepkisini çekti. Tüm bu krizlerle başlayan arayışlar karşısında yine Batı merkezli olarak postmodernlik, dünyaya önerilmiştir. Böylece postmodernlik ile modernliğin zaafiyetleri aşılmaya çalışılmaktadır. Aynı

\footnotetext{
Steven Lukes, Bireycilik, Çev.: İ. Serin (İstanbul: Ark, 1995), s. 15.

Immanuel Kant, Seçilmiş Yazılar, Çev.: N. Bozkurt (İstanbul: Remzi Kitabevi, 1984), s. 213.

4 Bkz. J. Donald Walters, Modern Düşüncenin Krizi-Anlamsızlık Sorununa Çözümler, Çev.: Ş. Yalçın (İstanbul: İnsan, 1995); Charles Taylor, Modernliğin Sikıntıları, Çev.: U. Canbilen (İstanbul: Ayrıntı, 1995), s. 12.
} 
paradigmadan beslenen modernlik ve postmodernliğin temel yönelimleri itibarıla (Batı-merkezlilik, insan merkezli evren vb.) birbirlerinin devamı olduğu bu noktada ortaya çıkmaktadır.

Batı-dışı ve özellikle müslüman toplumlarda modernizm bağlamında yaşanan son iki yüzyıllık tecrübe ve batılı hegemonya karşısında, postmodernliğin kurtarıcı olabileceği; özellikle modernliğin din karşısındaki tavrı ve totaliter niteliğinin bu zaafiyetleri aşmada imkana dönüşeceği beklentisi oluşmuştur. Bunun temel sebeplerinden birisi, postmodernliğin modernliği eleştirisi ise, bir diğeri postmodernliğin din ve özgürlüğe dair söylemlerinin müslümanlarda olumlu karşılık bulmasıdır. Hatta öyle ki, müslümanlar modernliğe karşı postmodernliğin içinden de cevap üretmeye çalışmışlardır. Yukarıdan beri anlatılan süreçte, dikkat edilirse iki kavram üzerinden bir takip yapılmıştır. Bunlar din ve totaliterliktir. Bu bağlamda makalemizin temel tezini şu şekilde ortaya koymak mümkündür; postmodernlik din karşısında özgürlükçü bir tutuma sahip değildir. $\mathrm{O}$, dinlerin kendi tabiatlarını bozma pahasına ancak kendi sistemine dahil etmektedir. Hatta özelde İslam'in temel anlatımlarında geçmiş dönemlerde problem olarak görülen zaafiyetleri beslemektedir. İkinci tezimiz de, bununla bağlantılı olarak, postmodernliğin getirdiği özgürlük imkanlarının görece bir anlam ifade ettiği; onun özgürlük önerilerinin insanın kendisini gerçekleştirmesini değil, tabiatının bozulması pahasına sağladığını ileri sürmekteyiz. Bu bağlamda, postmodernliğin külli karakterinin sanıldığının aksine totaliter olduğunu savunmaktayız. Şimdi bu iddiaları makalemizin sınırları çerçevesinde birkaç başlık altında denemeye çalışacağız.

Her şeyden önce postmodern düşüncenin, onun niteliklerinin ve gündelik hayattaki tezahürlerinin, bir çok noktada müslüman bir zihnin bariyerlerine çarpması söz konusudur ki, bu çarpmada "ara alan"da kalan kavramların ihatalı bir şekilde tartışılması gerekir. Ancak, makalenin sinırlı hacmi sebebiyle burada iki kavram/sorun etrafında bir analiz yaparak postmodernizmin "din" sorununu açımlamaya çalışacağız.

\section{Hakikat}

Hakikat, Tanrı, evren ve insan ile bunlar arasındaki ilişkileri anlatan gerçekliktir. İslam'ın bakış açısında, hakikatin merkezinde Tanrı vardır; Tanrı bizzat hakikat olup aynı zamanda bu hakikatin de kaynağıdır. İslam literatüründe "Cenab-1 Hak" derken, aslında bu temel gerçekliğe referansta bulunulmaktadır. Bu bağlamda hakikat, bir boyutuyla ontoloji, diğer boyutuyla epistemolojiyle ilintili olarak açımlanmalıdır. Tanrı' nın varlığ eden bir varlık olması, dünya, insan ve eşyanın "fena" sıfatıyla bu 
varlıktan kaynaklanması, bir yandan Tanrı ile insan arasındaki ontolojik farkı, diğer yandan da aralarındaki ilişkinin mahiyetini belirler. Dolayısıyla bu farklardan kaynaklanan bir hiyerarşi söz konusudur. Diğer yandan epistemolojik anlamda da, eşya, insan ve evren ile bunların hem kendi aralarında hem de Tanrı ile olan ilişkilerinin "bilgi"si, ontolojiyi tamamlayan ve anlaşılır kılan hakikatin ihata ettiği bir parçadır.

İnsan, kendi bilincine erdiği andan itibaren, kendisini kuşatan ve varlıkların hem mahiyeti, hem anlamları hem de konumlarını merak eder. Zira kendisini varlık dünyasının içine sağlıklı bir şekilde konumlandırması gerekmektedir. İnsanın hakikat arayışı dediğimiz şey budur. Aslında başından beri tüm din, ideoloji ve felsefelerin cevabını bulmaya çalıştıkları şey bu "hakikat"e dairdir. Dinler, bir evrensel hakikatin varolduğu tezinden hareketle, insana bu hakikatin (Tanrı, insan, dünya ve eşyanın anlamı, bunlara dair parçalı bilgiler) ana çerçevesini sunarlar; bu da tarih boyunca peygamberler ve kutsal kitaplar aracılığıyla Tanrı'nın insan ile konuşması şeklinde gerçekleşmiştir. İman da bu hakikate insanın katılması, yani şahitlik etmesidir. Dinler, ölümden sonraki ebedi hayatı da bu gerçekliğin içine dahil ederek ihatalı bir açıklama sunarlarken, ideoloji ve felsefeler ancak dünyevi sınırlar içerisinde bir açıklama yapmaya çalışırlar. Dinlerin de hakikatin kaynağında Tanrı varken, ideololer de çoğunlukla insan vardır.

Konunun daha iyi anlaşılmasını sağlamak üzere işlevsel olması açısından Batı tarihini üç döneme ayırabiliriz. İlki, din ve vahyin merkezde olduğu teokratik dönemdir ki, onu süreklilik ve kopuşlarla modern ve postmodern dönemlerin takip ettiğini söyleyebiliriz. Bu üç dönemi, önce hakikatin kaynağı açısından karşılaştırmak gerekirse şöyle bir sonucu karşımızda buluruz. Teokratik dönemde Tanrı vardır ve hakikat de Tanrı merkezli ve Tanrı kaynaklıdır. Evren, dünya, insan ve eşya ancak Tanrı' nın etrafında anlam ve konum kazanırlar.

Modern dönem, her şeyden önce Tanrı ile insan ve diğer varlıklar arasındaki ilişkilerin mahiyetinin değişimine dair bir içerikle karşımıza çıkar. Yukarıda da kısmen belirttiğimiz üzere, modern döneme geçişin aşamaları hakikate dair algılayıştaki kırılmaları bize vermesi bakımından üzerinde durulmayı haketmektedir. Bu anlamda, Rönesans'la birlikte tekrar yükselen hümanizma, insanı merkeze alırken, hakikatin kaynağını da Tanrı'dan insana doğru çevirmiştir. Aslında bu, Rönesans'la başlayan bir süreç değildir. Daha önce de sözgelimi Protogaras bu konuda önemli bir örnektir. O, "hakikat adlı eserinde yer alan meşhur sözüyle söylemek gere- 
kirse, 'insan her şeyin ölçüsüdür; varolanın da varolmayanın da; varolmayanın varolmadıklarının da" 5 derken bunu kastediyor olsa gerektir. ${ }^{6}$ Kanaatimizce insanlı tarihini başından bu yana "hakikat" in kaynağı bakımından Tanrı ile insan arasında gelgit yapan bir süreç olarak okumak mümkündür. Bilhassa Kur'an'ın Tanr1-insan ilişkisine dair hakikat bağlamında tarihe bakışı bizi böyle düşünmeye zorlamaktadır. Dolayısıyla modernizmin önemli ayaklarından birisinin hümanizma olduğunu söylemekte hiçbir mahzur olmasa gerektir.

Descartes felsefesi ile Tanrı'nın otorite alanları daraltılırken, Tanrı yavaş yavaş dünyadan el çektirilerek öte dünya ile sınırland1rılır. Aslında bu, hümanizmin sonraki zorunlu adımlarından birisidir. Bir diğer zorunlu adım da, Reform süreci ile birlikte bireyselleşme ve sekülerleşme şeklinde ete kemiğe bürünür. Bireyselleşme, insanı referans alarak Tanrı ile bağlarından koparırken, onu kendi kendine yeterli (müstağni) bir varlık haline getirir ve sekülerleşme ile de insanın temel amaç ve gayesini dünyaya yönlendirir. Aydınlanma ise, tüm bu adımlardan sonra, insanın kendine yeterli bir varlık olarak dünyayı kendisinin kurabileceği ve hakikati inşa edebileceği fikrini yükseltir. Bu adımlar üzerinde yükselen modernizm, evrensel bir hakikat olduğu fikrini (bu nokta dinlerin iddiaları ile aynıdır) dillendirmekle birlikte, bu hakikatin kaynağını insan olarak görmektedir. Ancak şu hususu belirtelim ki, buradaki insanı soyut bir şekilde "insanlık" şeklinde okumak mümkündür. Zira temel vurgu, artık insanın hakikatin kaynağı olduğu üzerinedir.

Modernizmin evrim ve ilerleme düşünceleri de aslında onun insan tasarımını tanımlamaktadır. İlerleme, tarihin düz bir çizgi üzerinde sürekli ileriye doğru gittiğini belirtirken, ileri-geri antagonizması kurarak kültür ve medeniyetleri bu çizgi üzerinde farklı yerlere konumlandırır. Bu çizginin temel belirleyicisi ve motive edicisi ise rasyonellik bağlamında akıldır. Aklın burada öne çıması, bir yönüyle Tanrısal otoritenin hakikat bağlamında hümanizma ile kabul edilmemesi; diğer yönüyle bunun doğal bir sunucu olarak insanın en yetkin hakikat inşa etme aracı kabul edilmesiyle ilintilidir. Bir başka deyişle, vahiy yerine rasyonel akıl ikame edilmiştir.

İlerleme çizgisinin sonunda Batı bulunduğu, Batı dışındaki diğer toplumların ise bu çizginin farklı konumlarında ama mutlaka Batı'nın gerisinde yer aldığı anlayışı, ilerleme için zorunlu olarak bu

Hüsamettin Erdem, İlk Çă̆ Felsefesi Tarihi, 3. Baskı (Konya, y.y.), s. 122.

Hümanizmin tarihsel ve düşünsel serüveni konusunda geniş bilgi için bkz. Boğas Zekiyan, Hümanizm (İnsancıllk) Düşünsel İ̧lem ve Tarihsel Kökenler (İstanbul: İnk1lap ve Aka Kitabevi, 1982). 
aklı gerekli görmekteydi. Bunun anlamı; Batı-dışı tüm toplumların Batı'nın geçtiği aşamalarda aynı aklı kullanarak geçeceği şeklindedir. "Aklın soyut tanımı ve nihayetinde hakikatin yegane kaynağı olarak konumlandırılması, modern zamanların bir kurgusudur. Bu bağlamda akıl, nötr, tarafsız, kültür ve tarih-üstü bir algılayışın konusu olmaktadır. Bu durum aslında, Batı aklının kendisini örtük bir biçimde evrenselleştirme temayülünden kaynaklanmaktadır. Dolayısıyla nötr ve tarih-üstü akıl sunumunun gerçekte kolonileştirme anlayışının parçası haline geldiğini görmek lazımdır."7 Tüm bu bilgilere dayanarak, modernizmin evrensel tek hakikat fikrini kabul ettiğini; ancak bunun insan kaynaklı bir tek hakikat olduğunu söyleyebiliriz.

Teokratik dönemden modernliğe geçerken, hakikatin kaynak ve referansının değişmesi, hakikatin mahiyetine dair bir dönüşümü sonuçlamaktadır. Her şeyden önce insan, evren ve Tanrı'ya dair hakikatin reddi ortaya bir vakumu çıkarmıştır. Tam da bu sebeple Baudrillard, Tanrı'nın yeryüzünden çekilişi ile insanın gerçeklikle yüzyüze kaldığını söylemektedir. ${ }^{8}$ Bunun bir anlamı da hakikatin insani kapasite ve imkanlarla yeniden inşasıdır. Halbuki ontolojik olarak Tanrı ile insan arasındaki farklılık, hakikatin insan tarafından inşası bir yana, insanın hakikati ihatalı bir kavrayışını da mümkün kılmaz. Dolayısıyla hakikat inşası, insanın boyutunu aşan bir durumdur. Tüm bunların doğal bir sonucu olarak modernizmde hakikat insanın sinurları dahilinde ve ister istemez mahiyetinden kaybederek "insan" ın sınırları dahilinde sıkışmak durumunda kalmıştır. Fizik/metafizik, içkin/aşkın tüm dualiteleri kapsayan tanrısal hakikat, böylece sadece fizik ve içkin alanı içine alan bir irtifa kaybına uğramıştır. Ancak, bu insan, dünya, Tanrı'ya dair ihatalı bir açıklama biçimi sunmadığından, hakikati anlatma konusunda da problemlidir.

Modernizm, bu perspektiften değerledirildiğinde, Tanrı'ya karşı soyut insanı, vahye karşı aklı, tanrısal hakikat yerine seküler evrensel hakikati yerleştirmeye çalışmaktadır. Taylor'ın da isabetli olarak bahsettiği üzere bu, topluma karşı bir kayıtsızlığı getirdiği gibi, dünyanın büyüsünün çözülmesi (yani dinsel ihatayı kaybetmesi M.T.) ve araçsal aklın öncelik kazanmasını sonuçlamaktadır. Taylor'a göre, varlıklar varoluş zincirlerinde anlam ve konumlarını kaybettiklerinde insan projeleri için hammadde ya da araç olarak görülmeye de açık hale gelirler. ${ }^{9}$ Bunun anlamı; insanın Tanrı,

7 Mustafa Tekin, "Ak1l/lar ve İslam Aklı", Diyanet Aylık Dergi, s. 297, Ankara, Eylül-2015, s. 59.

8 Jean Baudrillard, Şeytana Satılan Ruh Ya da Kötülü̈̆̈̈̈n Egemenliği, Çev.: O. Adanır (Ankara: Doğu Batı, 2005), s. 17.

9 Taylor, Modernliğin Sikıntıları, ss. 10-13. 
dünya, insan ve çevre ile kurduğu ilişkilerde yüce gayelerin dünyevi kısa vadeli hedeflere dönüşü hale gelmeleridir ve bu hedefleri gerçekleştirdikleri oranda anlamlıdırlar. Tam da bu noktada Touraine, modern toplumların karakteristiği olarak araçsalcı akılcı eylem ile kişisel özne arasındaki ayrılık ve bağımlılığa dikkat çekmektedir. Ona göre, araçsal akılcı eylem kişisel özneyi bilmezse, topluma ve tutumların işlevselliğine tapınmaktadır; yok eğer kişisel özne araçsal akılcılı̆̆ 1 dışlarsa, nitelik değiştirerek bireysel ya da toplumsal kimliğe tapınmaya dönüşmektedir. ${ }^{10}$

Modernizm, bu çerçevede kendi hakikat anlayışını da "dinsel bir gerçeklik" kesinliğinde sunumlamıştır. Bu sunumlama ile hakikatin genetiği bozulmuştur. Postmodernlik, tam da modernliğin handikaplarının konuşulduğu yerde devreye girmektedir. Bu bağlamda onu, modernlikle bağlantılı kılan noktalardan biri, modernizme getirilen eleştirilere cevap olmasıdır. $\mathrm{Bu}$ durum postmodernizmin bir yandan modernizme dair bir bilinç ${ }^{11}$ şeklinde anlaşılmasını sağlarken, diğer yandan yeninin genişlemesine de atıfta bulunulmaktadır. ${ }^{12} \mathrm{Bu}$ anlamda "Postmodernlik klasik hakikat, akıl, kimlik ve nesnellik nosyonlarından, evrensel ilerleme ya da kurtuluş fikrinden, biçimsel açıklamanın başvurabileceği tekil çerçeveler, büyük anlatılar ya da nihai zeminlerden kuşku duyan bir düşünce tarzıdır. Postmodernlik, Aydınlanma'nın bu normlarına karşı dünyanın olumsal, temelsiz, çeşitli, istikrarsız, belirlenmemiş nitelikte ve bir dizi dağınık kültürlerden ya da yorumlardan ibaret olduğunu bildirir."13 Böylece postmodern düşünce açısından keşfedilecek hakikat kalmamıştır. ${ }^{14}$ Postmodernizm her şeyden önce, tek evrensel hakikat fikrine meydan okurken, diğer yandan “bütün”lük anlayışından uzaklaşarak parçalanmış bir hakikat düşüncesi yaratır. Böylece modernizm soyut insanı Tanrı'nın yerine ikame ederken, postmodernizmde tüm insanlar birer Tanrı haline gelirler.

10 Alain Touraine, Modernliğin Eleştirisi, Çev.: Hülya Tufan, 3. Baskı (İstanbul: Yapı Kredi, 2000), s. 241.

11 Ernest Wolf-Gazo, "Postmodernizmin Aydınlanmayı Eleştirisi", Çev.: Ş. Deniz, İslami Araştırmalar, c. 6, s. 1, Ankara, 1992, ss. 1-4.

12 Michael York, "Postmodernity, Architecture, Society and Religion: A Heap of Broken Images or A Change of Heart", Postmodernity, Sociology and Religion (London: McMillan Press, 1966), s. 51.

13 Terry Eagleton, Postmodernizmin Yanılsamaları, Çev.: M. Küçük (İstanbul: Ayrıntı, 1999), s. 9.

14 Pauline Marie Rosenau, Post-Modernizm ve Toplumbilimleri-İçe-bakışlar, İçeri-dalışlar, İçeri-saldırılar, Çev.: T. Birkan, 2. Baskı (Ankara: Bilim ve Sanat, 2004), s. 26. 
Tüm bunların doğal sonucu olarak hakikat, insan sinırlarında göreli hale gelir ki, bunun anlamı bir yandan hakikatin yokluğu diğer yandan insanın tüm tutku ve taleplerinin meşrulaştırılmasıdır. Sonsuz bir tekillikler silsilesi ile kaos ve belirsizliği besleyen postmodernizm, tüm hakikat, gerçeklik ve doğrulardan kuşkuya çağırır. Tutku ve taleplerin meşrulaştırılması ve hakikatten kuşku birleşince, dış gerçekliğin ifade ettiği bir anlam kalmaz. Nihayetinde postmodernlikte yorumun gerçekliğin önüne geçmesi; bir başka deyişle her şeyin bir yorum haline gelmesi söz konusudur. Dini anlayış Tanrı ve vahyi, bir gerçeklik, insan yorumlarını da buna dair bir konuşma olarak kabul eder ki, yorum gerçeklikten bağımsız olamaz ve gerçekliği iptal edemez. Modernlikte ise hakikat, insanın gerçekliğe dair bir takım yöntemlerle elde ettiği insan kaynaklı bir nitelik taşır. "Düşün-gerçek ikileminin geçersizleştiği postmodern bir tabloda, düşünceden bağımsız bir objektif gerçekliğe yer yoktur. Gözlem kuram yüklüdür ve gerçeklik teori bağımlıdır. Objektif bir dış dünya varsayımının terkiyle modern epistemolojilerin insan düşüncesine yüklediği işlevde somutlaşan epistemolojik sorunsal da anlamını yitirmektedir. Objektif bir dış dünya sözkonusu değilse eğer, düşünceyi objektif bir diş gerçekliğe tekabül ettirme ya da gerçeklikle düşünsel izdüşümü arasında bir denklik kurmak bir sorunsal olarak ortadan kalkmaktadır."15 Tanrı'yı bilgi süreçlerinden dışlayan modernizm için, üretilen bilgilerin hakikatle tekabüliyeti sorunlu olabilir. Burada postmodern eleştiriler haklıdır. Ancak, Tanrısal hakikatten bahsedeceksek, böyle bir handikapın özü itibarıyla olmaması gerekir.

Postmodernizmdeki kuşku süreklidir ve sisteme dahildir. O, her şeyi metin-yorum çerçevesinde okurken, sistemi kuşkuculuğa ve gerçekliğin olmayışı üzerine dayanmaktadır. Postmodernizmin bu noktada kullandığı temel kavram ise yapısökümüdür. Bu anlamda "Postmodernizm kendisini modern paradigmanın dışında kurmayı, modernliği kendi ölçütleriyle yargılamaktansa üzerinde düşünüp yapıbozumuna uğratmayı önerir." ${ }^{16}$ Bu tikel ve tümel gerçeklikleri yadsımaktadır. "Yapısöküm yöntemi, herhangi bir metin içerisinde geçen kavramların metnin bütünlüğü açısından tutarsız ve ikircikli kullanımlarından yola çıkarak, metnin yazarının kurduğu kavramsal ayrımların başarısızlığını açıklamak amacıyla geliştirilmiş bir metin okuma yöntemidir. Başka bir deyişle, bu yöntem metinde öngörülen ölçütü, metnin kurduğu ölçüt ya da tanımları

15 Ahmet Kara, "Post-Modern Epistemolojiler ve Modern Bilim", Bilgi, Bilim ve İslam (İstanbul: İSAV, 1992), s. 156.

16 Rosenau, Post-Modernizm ve Toplumbilimleri, s. 21. 
sökerek metnin içerdiği özgün anlamları darmadağın etmek için kullanılır."17 Böylece metin istikrarsızlaşır.

Postmodern anlayış içerisinde dinin konumu da, bu istikrarsızlıktan payını almaktadır. Zira hakikatin reddi ve doğruluğun göreceli hale gelmesi dinler ve özelde vahyî dinleri yerinden eder. Postmodernizmde dinler, ancak tekil insan sınırları içerisine sıkışarak kendilerini ifade ederler ki, dinlerin "kendi"liği böylece bozulmaktadır. Halbuki dinler, evrensel dinsel bir hakikat üzerine dayanmaktadırlar. Modernizm, dinin ihatalı alanlarını indirgemeye tabi tutatak daraltırken, postmodernizm bunu kökten reddeder. “Bu aşırı durumda postmodernizm, bağ anlamına gelen religio olarak dinin bizzat özünü ya da herhangi bir tanımını temelden yoksun kılar."18 Bu anlamda postmodernizm, dine kendi anlam çerçevesinde bir dizi işlemden geçmesini teklif etmektedir.

$\mathrm{Bu}$ işlemlerin birincisi, postmodernizmin dinlerin evrensel hakikat iddialarını reddetmelerini istemesidir. Dinlerin, Tanrı, insan, evren ve bunların ilişkilerine dair önerdikleri hakikat, postmodernizmde bir sorunsala dönüşmektedir. Zira tüm insanları kapsayan bir hakikat ve doğru yoktur. İkincisi, yine bununla bağlantılı olarak "bütün"lük fikrinin terk edilmesidir ki, çoğulculuk bunun kültürel, siyasal, ve toplumsal bir tezahürüdür. Üçüncü olarak da, bu parçalanma senkretik bir din anlayışıyla sonuçlanmaktadır. Yani çok farklı dinlerden farklı ögelerin biraraya getirilmesiyle oluşan yeni bir din. Bu durum Rosenau'nun deyişiyle, herkesin onda (postmodernizmde, M. T.) bir şeyler bulabildiği bir kes-yapıştır karakterine tekabül etmektedir. ${ }^{19}$ Anderson da, yeni evrensel bir dinin gezegenin geleceğini güvence altına alacağını, ancak bunun da devşirmeci (senkretik olması) gerektiğini belirtir. ${ }^{20}$

Hakikat bağlamında postmodernizmde önemli bir tartışma konusu olan nokta da imaj ve gerçeklik ilişkisidir. Her şeyden önce gerçekliğin bu şekilde reddi, yorumun hakikatin önüne geçmesi gerçekliğe dair bir sorunsalı ortaya çıkarmaktadır. Bu anlamda, "Postmodernizmin temel kavramların biri olan hipergerçek de, gerçek ile gerçek olmayan arasındaki çizginin bulanıklaştığ 1 bir durumu ifade etmektedir ki, burada "hiper" öneki, gerçeğin bir model

17 Madan Sarup, Post-Yapısalcılık ve Postmodernizm, Çev.: A. Güçlü (Ankara: Bilim ve Sanat, 2004),ss. 54-55.

18 Pamela Sue Anderson, "Postmodernizm ve Din", Postmodern Düşüncenin Eleştirel Sözlü̆̆̈̈, Ed.: S. Sim, Çev.: M. Erkan-A. Utku (Ankara: Ebabil, 2006), s. 59.

19 Rosenau, Post-Modernizm ve Toplumbilimleri, s. 34.

20 Perry Anderson, Postmodernitenin Kökenleri, Çev.: E. Gen, 3. Baskı (İstanbul: İletişim, 2005), s. 13. 
uyarınca üretilmesiyle ortaya çıkan gerçeğin, gerçekten daha gerçek olduğunu ifade eder." 21 İmaj ve gerçek arasındaki bu bulanıklık (ki gerçekte bir krizdir), bir müddet sonra imajın gerçekliğin yerini almasıyla sonuçlanır ki, imajlar aslında paradoksal olarak (postmodernlik açısından paradokstur) yeniden yaratılan gerçekliklerdir. Baudrillard, "bugünün hastalığının gerçekliğin üretimi ve yeniden üretimi olduğunu"22 söylerken, burada "üretim" kelimesini kullanarak sürecin dinamikliğine dikkat çeker. Biz de "yaratılan" derken, bu dinamikliği dişlamamakla birlikte, insanın bir hakikate olan zorunlu ihtiyacını kastetmekteyiz. Bu bağlamda "simülasyon" kavramını kullanan Baudrillard, bunu "gerçekliğe kısa devre yaptırılarak göstergeler aracılığıyla yaratılan şey" 23 şeklinde tanımlar. Böylece gerçeklik göstergeler arkasında kaybolmaktadır. Baudrillard ikonastlardan bahsederken, Tanrı'nın da ancak simulakrları aracılığıyla varolduğu, hatta simulakrlarından başka bir şey olmadığı bir dünyaya dikkat çekerken ancak imgelerle oynanan bir Tanrı oyunundan bahsetmektedir. ${ }^{24}$ Dolayısıyla Tanrı da bir hakikatin kaynağı olmaktan çok, "insan” imgeleriyle üretilen bir varlık olur. Artık Tanrı hakikat buyurmaktan uzaklaşmış ve insanın imajinatif olarak ürettiği bir varlık haline gelmiştir.

Postmodernizmin temel karakteristiği bu çerçevede iken, onu İslam ya da vahiy için bir imkan olarak gören kimi yaklaşımlar da mevcuttur. Bu iddiada, "postmodern dünya görüşünün ortaya çıkması, akıl ve tecrübe temeline dayalı epistemolojiye ters düşmeyen, aksine onunla birlikte olması zorunlu kabul edilen vahyi bilgiyi Tanrı inancının elde edilmesinde kullanılmasına izin verileceği varsayılmaktadır." 25 Bir kere postmodern dünya görüşünün akıl kadar vahyi bilginin içerdiği hakikatle de birarada olması düşünülemez. Postmodernizmin Aydınlanma'nın rasyonel aklına ve aklın bu şekilde hakikatin evrensel inşasında kazandığı otoriteye itirazı vardır. Postmodernizmin, kendi bünyesinde yer verdiği din, işlemden geçirilerek ancak bu çerçeve içerisinde yeniden tanımlanan, kendi bütünlüğünden yoksun, hakikat iddiasını terketmiş senkretik bir karakter taşır. Böyle bir başkalaşım geçiren dinin ise, "kendi"si olarak kaldığını iddia etmek kadar, bir imkan açacağını da düşünmek zordur. Müslüman dünyada postmodernizme yönelik sempatik

21 Steven Best-Douglas Kellner, Postmodern Teori-Eleştirel Soruşturmalar, Çev.: M. Küçük (İstanbul: Ayrıntı, 1998), s. 149.

22 Jean Baudrillard, Simulakrlar ve Simülasyon, Çev.: O. Adanır, 3. Baskı (Ankara: Doğu Batı, 2005), s. 44.

23 Baudrillard, Simulakrlar ve Simülasyon, s. 50.

24 Baudrillard, Simulakrlar ve Simülasyon, s. 18-19.

25 Mevlüt Albayrak, "Dine Ya da Tanrıya Yeniden Yer Açma Çabası Olarak Postmodernizm ve Çoğulculuk", Tabula Rasa-Felsefe E Teoloji, s. 11, Isparta, 2004, s. 6. 
eğilimler, içerdiği modernizm eleştirisi ve dine yönelik daha 1lımlı görünen tavırlarından kaynaklanmaktadır. Gerçekte postmodernizm, hakikati reddine ek olarak yapısökümü ile, kuşkuyu beslemekte, insanı ortada bırakmakta; dolayısıyla insanı en baştan kendisi ile krize sokmaktadir.

\section{Özgürlük/Totalitarizm}

Postmodernizme müslüman dünyada bazılarınca olumlu yaklaşılmasının ikinci sebebi de, modernizmin din konusundaki katı tutumunun postmodernlikle aşılabileceği düşüncesidir. Bilindiği gibi postmodernizm, hem dinleri hem de modernizmi "tek evrensel hakikat" olma iddiası sebebiyle eleştirir; evrensel hakikat fikrinin özünde dayatmacı ve özgürlük karşıtı olduğunu düşünür. Bu anlamda dinlerin "Tanrı hegemonyası", modernizmin ise tek evrensel hakikat fikrinden mülhem insani bir hegemonya ürettiğini belirtir. Ortaçağ' da kilise ve modern zamanlarda Batı modernitesi bu hegemonyaların görünen tezahürleridir ve postmodernizmin bu eleştirilerinde haklılık payı bulunmaktadır.

Fakat burada bir farkı kısaca ortaya koymak zorundayı. Batı'da Ortaçağ teokratik bir yönetim biçimine dayanmaktaydı. Bu anlamda teokrasi, "siyasal örgütlenmenin, devletin yönetim organlarının, tüm siyasal ilişkilerin ve iktidarın din adamları tarafından düzenlenip yürürtüldüğü yönetim biçimi" 26 olup, Tanrı adına din adamlarının yönetimidir. Ortaçağ'da papalık ve ruhban sınıfının iktidarı, bu bağlamda okunabilir. Fakat İslam'ın yönetim anlayışı bir teokrasiye dayanmaz; zira din adamı sınıfı yoktur. Ancak postmodernizm dini, evrensel Tanrı kaynaklı hakikate dayandığı için eleştiri konusu yapmaktadır. Öte yandan Batı modernitesinin hem Avrupa'da hem de Avrupa dışında, tüm gerçekliği kendi elinde tuttuğu yolundaki tutumları, ciddi bir hegemonya üretmiştir. Bu hegemonyayı I. ve II. Dünya savaşları, Avrupa'nın ortasında ortaya çıkan faşist iktidarlar üzerinden izlemek mümkündür. Öte yandan dünyanın farklı bölgelerinde Batı modernitesinin yol açtığı işgal, kriz ve sömürüler de önemli göstergelerdir. Yine Batı'da Romantizm, varoluşçuluk gibi akımlar da moderniteye tepkiyi ifade etmektedirler. Zaten postmodernizm de, modernizmin bu anlamda totaliter doğasına itirazlarda bulunmakta ve kendisini özgürlükçü ve anti-totaliter olarak tanımlamaktadır.

Şimdi postmodernizmin bu konudaki yaklaşım ve iddialarına daha yakından bakabiliriz. Postmodernizmin özgürlük bağlamındaki en sıkı iddiası, tek hakikat düşüncesinin (ister Tanrı kaynaklı,

\footnotetext{
26 Sosyal Bilimler Sözlüğü, Ö. Demir-M. Acar (İstanbul: Ağaç, 1992), s. 354.
} 
ister insan kaynaklı) son kertede bir totalitarizmi besleyeceği yönündedir. Halbuki bu argüman doğru değildir. Birinci boyut; Tanrı, insan ve evren ile bunlar arasındaki ilişkileri, fizik/metafizik, dünya/âhiret dualitelerini yaratmadan anlatan hakikat fikri, Kur'an'da insana bir rehberlik olarak sunulmaktadır. ${ }^{27}$ Toplumsal düzlemde, bu hakikatin kabul edilip edilmemesi, insanın kendi irade ve özgürlükleri içerisinde değerlendirilir ${ }^{28}$ ve bir imtihanın konusudurlar. Her ne kadar bu hakikati kabul etme bağlamında Kur'an mü'min/kafir nitelemelerini kullanıyorsa da, toplumsal düzlemde mü'min/kafir kategorileri bir arada yaşarlar; dolayısıyla bu, bir ayrımcılık ve baskı aracı olarak kabul edilemez. Bu konuda bilhassa "Tevhid"in totaliterleştirici bir doğası olduğu ve son tahlilde çoğullukları kaldırarak bir hegemonyaya dönüşeceği ${ }^{29}$ iddia edilir. Tevhid'in postmodern bir düşünme biçimine başta eleştiri içerdiği söylenebilir, ancak bu hakikatin kaynağının sadece Tanrı olduğuna atıfta bulunmaktadır. Yoksa totaliter bir dönüştürmenin aracı değildir.

Postmodernizm, din ve modernizmin kültür, din, felsefe ve yapılanmalar arasında koyduğu hiyerarşiye karşı çıkarken, bu hiyerarşinin bir baskı aracı yarattı̆̆ı tezinden hareketle, yanyanalık easasını getirir. Böylece bir yandan alt-üst kültür, "doğru", "hakikat" bakımından ayrımları reddederken, öte yandan hiçbiri diğerinden daha "gerçek" olmayan kültür, din ve felsefelerin sıralanması söz konusu olmaktadır. Diğer yandan postmodernizm, din ve felsefeleri iddialarından geri çektirerek onların bir kültüre dönüşmelerini sağlar. Her bir kültürün de "doğru"luk iddia alanı, ancak kendi sınırları içerisindedir ve diğeriyle karşılaştırılabilme imkanı yoktur. Burada aslında iki tür totalleştirme söz konusudur. Birincisi, din ve felsefelerin iddialarından arındırılarak birer kültüre dönüștürülmesi, postmodernizmin totaliter tavrıdır. Çünkü bir "yapı" yı bütünlüğü ve mahiyetinden kopararak "kendi"liğinden uzaklaştırmaktadır. Bunun sosyal alanda birçok tezahürlerini izlemek mümkündür. "Burada gerçek bir özgürlükten bahsetmek imkan dahilinde değildir. Dünya sistemi, televizyondan internete ve gündelik hayata kadar bu yaşam tarzını onaylayacak bir sosyalleşmeden insanları geçirmekte; oluşan aura insanların bunların dışındaki talep ve düşüncelerini gayr-1 meşru ilan etmekte ve tüm mekanizmalarıyla insanları sürüleştirerek iradelerini ellerinden al-

2/Bakara, 2.

18/Kehf, 29.

Ali Yaşar Sarıbay, Postmodernite, Sivil Toplum ve İslam, 2. Baskı (İstanbul: İletişim, 1995), ss. 11-12. 
maktadır. Bunun dışındaki davranışları, kurduğu yeni aforoz sistemiyle cezalandırmaktadır. Bu aforoz sistemi, sisteme uymadığı taktirde büyük bir mahrumiyet duygusuyla fertlerin ruhlarına acı vermekte, onların ne düşüneceği, ne giyeceği, nasıl yaşayacaklarını birebir detaylarıyla işlemektedir. Toplumlar da bu dünya sistemi tarafından sürekli kontrol edilmektedir." 30

İkincisi de, "Kimsenin kimseyle kıyaslanabilir olmadığı bir toplum oluşturmak istediğimizi savunmak, kaçınılmaz olarak totalleştirici, evrenselci bir iddiada bulunmaktır."31 Eagleton, postmodernizmin bu iddiasının bile bizzat, evrensel bir iddia anlaminda postmodernliğin kendisine meydan okuduğunu anlatmaktadır. Öte yandan meselenin şöyle bir boyutu da vardır. Postmodern mentalite, her insanın kendi sınırları içinde geçerli tezlere sahip olması ile çatışmanın ve hegemonyanın sona ereceğini savlamaktadır. $\mathrm{Bu}$ anlayışın sonucu ya, iletişimsiz bir bireyselleşme ya da "güç" araçlarını eline geçirenlerin diğerleri üzerinde kuracağı hegemonyadır. Postmodernizm, yanyanalıkla çatışma ve hegemonyanın önleneceğini düşünür, ancak bunun politik ve toplumsal süreçlerle ilişkisini ihmal eder. Diğer yandan postmodernizmin bu yanyanalıkların birbirleriyle ilişkilerine dair ilkeleri ile, daha uzun vadede devlet, toplum gibi kolektiviteleri nasıl oluşturacağ ciddi sorunludur. Zira bu ilkeleri belirlemek tekrar evrenselciliğe dönüş olur ki, bir bumerang gibi postmodernliğe eleştiri olarak geri döner. Bu anlamda insanı korumasız bırakan postmodern süreç, yine gücün hegemonyasını üretecektir. Bu güç ise, asla Tanrı gibi insan üzerine şefkat ve merhametli olmayacaktır.

İnsan merkezli ideolojilerde özgürlük, çoğunlukla insanın talep ve tutkularının önündeki engellerin mümkün olduğunca ileri noktalara ulaşacak derecede kaldırılması şeklinde içeriklendirilmektedir. Modernizmde de bu, Tanrı'ya rağmen kazanılan bir durumdur ve Tanrısal otoritenin daraltıldığı oranda artacağ 1 düşünülür. Bu bağlamda özgürlüğün kaynağı da Tanrı değil insandır. Postmodernizm de de özgürlüğün kaynağ değişmez ancak birebir somut insanın öznelliklerinin tümü özgürlügüün konusu olur ve özgürlüğün sınır(sızlığ)ını belirler. Funk'a göre, “postmodern ben-odaklı karakter, özgür, spontane, bağımsız bir biçimde, kendini kural ve ölçülerle sınırlamadan bütün gücüyle kendi yaşamını kendisi

\footnotetext{
30 Mustafa Tekin, Toplumun Vicdanı Olmak (İstanbul: Açllımkitap, 2015), s. 31.

31 Eagleton, Postmodernizmin Yanılsamaları, s. 142.
} 
belirlemeye çalışmaktadır." ${ }^{32} \mathrm{Bu}$, insanın bütün talep, arzu ve tutkularının meşrulaştırılması ve insanın özgürleştirilmesi için bunların önündeki engellerin kaldırılması anlamına gelmektedir.

Burada gözardı edilen üç sorun bulunmaktadır. Her şeyden önce postmodernliğin bahse konu olan özgürlük anlayışının "insan" ile tekabüliyeti sorunludur. İnsanın tüm talep, arzu ve tutkuları kendisi için "iyi" değildir. Kur'an insana fücür ve takvanın birlikte verildiğinden bahsederken ${ }^{33}$, onun ayn anda iyi ve kötülüğe meyilli tabiatına işaret etmektedir. Talep, arzu ve tutkularının tümüyle yerine getirilmesi insanda bozulmayı da getirmektedir. Tam da bu sebeple İslam, tutkuların kontrol edilmesi esasına dayanmaktadır. "Bir şeye meftun olmak" 34 anlamına gelen heva, kontrol edilmediği taktirde insanı o tutkuların kölesi haline getirir. Kur'an, "hevasını ilah edineni görmedin mi?"35 derken insanın arzu ve tutkularının elindeki esaretine değinir. Gerçekte özgürlük, tutkuları kontrol etmek suretiyle insanı onlardan özgürleştirmekle başlar.

Bununla bağlantılı ikinci sorun, insanın mahiyetine dairdir. Tanrı ile insan arasında bir mahiyet farkı bulunmaktadır; bu anlamda "insan" in ontolojik olarak mutlak özgürlüğünden bahsedilemez, tam tersine insanın potansiyel ve imkanları sinırlıdır. Özgürlük gerçekte, insanın tüm istediklerini yapabilmesi değil, bu imkan ve sınırlılıkları gözeterek önüne alan açmasıdır. Bu anlamda yollar, araçların özgürlük imkanıdır. Yol olmadığı zaman, arabaların özgürlük imkanından bahsedemeyiz. Postmodernizm, insanın potansiyel imkan ve sınırlılıklarını tartışmadan ona mutlak özgürlük vadetmektedir ki, bu bir sanal özgürlüktür. İnsan öznelliklerinin tümünün özgürlügün konusu olması, ancak şiddeti ve totalitarizmi besleyecektir. Zira insan ihtiraslarının sınırlandırılması gerekir; aksi halde çatışma, savaş ve totaliterlik kaçınılmaz görünmektedir. Diğer yandan postmodernizm insanın dünyada bulunuşunu herhangi bir üst değerden bağımsız tanımladığı için, insanı tamamen dünyevî, tutkularıyla başbaşa bırakmaktadır. Halbuki dinler, insanı bir üst değerle bağlantılı kıldıklarından dünyada bulunuşa da bir anlam ve değer kazandırmaktadır. Daha da ileri giderek din, insanı sorumlu kılması hasebiyle tercihlerine bir anlam katar; böylece her seçimi (iradesi) maliyet gerektiren insan için özgürlük de kendi konumuna insanda kavuşur.

\footnotetext{
32 Rainer Funk, Ben ve Biz-Postmodern Insanın Psikanalizi, Çev.: Ç. Tanyeri, 2. Baskı (İstanbul: Yapı Kredi, 2009), s. 55.

33 91/Şems, 8.

34 Mevlüt Sarı, El-Mevarid (İstanbul: Bahar, 1982), s. 1619.

35 25/Furkan, 43.
} 
Üçüncü sorun da, insanın tutku, arzu ve taleplerinin önünün açılması, insanı kendisine yabancılaştırdığı gibi onu imajinatif bir dünyanın içine sokmaktadır. Funk'ın deyişiyle, kendi özerkliğini hayata geçiren yani kendisini içeriden belirleyen post-modern benodaklı karakterin bu tür bir özerklikle bir yere varması söz konusu değildir. Zira bu benlik, her defa yeniden yaratılan bir gerçekliğin üretimi sonucu gerçekleşmektedir. ${ }^{36}$ Dolayısıyla kendisine farklı bir gerçeklik dünyası oluşturan insan, dış dünya ile sorunlu hale gelmekte; onunla arasındaki mesafe açıldıkça kendi gerçeklik dünyasını dışarıya yansıtmakta ve diğerlerini baskılamaktadır.

Modernizm inşa ettiği hakikati baskı, açık işgal ve sömürü ile dayatmıştı. Dünyada son birkaç yüzyıldır yaşanan olumsuzluklarda bunu izleyebiliriz. Postmodernlik ise, insan öznelliği üzerine kurduğu imajinatif dünya ve kendi sanal gerçekliği içerisine dahil olmayanları aforoz sistemi ${ }^{37}$ ile yola getirmeyi denemektedir.

\section{Sonuç Yerine:}

Batı dünyası modernlikle birlikte ciddi bir dönüşüm yaşadı. Bu dönüşümün etkileri ise hiç şüphesiz sadece Batı ile sınırlı kalmadı. Bu anlamda modernizm kilisenin hegemonyasından kurtulmak üzere yeni bir anlayış ortaya koydu. Bu anlayış, hakikatin yeniden inşası, insanın merkeze alınması ve özgürlük talepleriyle öne çıkmıştı. Fakat ilerleyen süreç, dünyanın yeni bir hegemonya ile karşı karşıya kaldığını gösterdi. Bunun üzerine "postmodernizm", bir kurtarıcı düşünce ve yaşam tarzı olarak önümüze geldi. Modernizmin yöntemlerinden farklılaşması, onun bir ümit olarak görülmesine yol açtı; özellikle yeni bir gerçeklik ve özgürlük iddiası sebebiyle.

Bu makalede, "hakikat" ve "özgürlük/totalitarizm" başlıkları üzerinden postmodernizmin önerileri "din" bağlamında analiz edilmiştir. Bu analiz neticesinde, postmodernizmin savlarındaki problemler dile getirilmiştir. Aydınlanma'ya eleştiri getirmekle birlikte, "insan" 1 Tanrı karşısında bir referans olarak görmeye devam etmesiyle postmodernizm, insanın hakikat ve özgürlügüüne dair krizlerini derinleştirmiş görünmektedir. $\mathrm{Bu}$ bağlamda, başta sunduğumuz gerek "postmodernizmin" dini ve hakikati; dolayısıyla insan tabiatını bozduğu, dinleri postmodern çerçeveye sıkışmaya zorlayarak bir şiddet uyguladığı, gerekse insan için tanımladığ 1 özgürlüğün totaliter ve krizli bir dünya yarattığ1 meâlindeki tezimiz doğrulanmış görünmektedir. Kanaatimizce temel sorun; insanin makro (modern) ya da mikro (postmodern) haliyle Tanrı yerine ikame edilmesinden kaynaklanmaktadır. Postmodernizm de modernizmle başlayan Tanrı ile sorunlu ilişki

36 Funk, Ben ve Biz-Postmodern Insanmn Psikanalizi, s. 60.

37 Mustafa Tekin, Toplumun Vicdanı Olmak, ss. 30-32. 
konumunu devam ettirmektedir ve bu haliyle bir özgürlük vadetmemektedir. Dolayısıyla sorunları poszmodernizmle aşma imkanı yoktur. Zira sorunlar, sorunu yaratan mentalite içerisinden aşılamazlar.

\section{Kaynakça}

Ahmet Kara, "Post-Modern Epistemolojiler ve Modern Bilim", Bilgi, Bilim ve İslam (İstanbul: İSAV, 1992).

Alain Touraine, Modernliğin Eleştirisi, Çev.: Hülya Tufan, 3. Baskı (İstanbul: Yapı Kredi, 2000), s. 241.

Ali Yaşar Sarıbay, Postmodernite, Sivil Toplum ve İslam, 2. Baskı (İstanbul: İletişim, 1995).

Boğas Zekiyan, Hümanizm (İnsancllı) Düşünsel İçlem ve Tarihsel Kökenler (İstanbul: İnkılap ve Aka Kitabevi, 1982).

Charles Taylor, Modernliğin Sıkıntıları, Çev.: U. Canbilen (İstanbul: Ayrint1, 1995).

David Harvey, Postmodernliğin Durumu-Kültürel Değişimin Kökenleri, Çev.: S. Savran (İstanbul: Metis, 1999).

Ernest Wolf-Gazo, "Postmodernizmin Aydınlanmayı Eleştirisi", Çev.: Ş. Deniz, İslami Araştırmalar, c. 6, s. 1, Ankara, 1992, ss. 1-4.

Hüsamettin Erdem, İlk Çağ Felsefesi Tarihi, 3. Baskı (Konya, y.y.).

Immanuel Kant, Seçilmiş Yazılar, Çev.: N. Bozkurt (İstanbul: Remzi Kitabevi, 1984).

J. Donald Walters, Modern Düşüncenin Krizi-Anlamsızlık Sorununa Çözümler, Çev.: Ş. Yalçın (İstanbul: İnsan, 1995).

Jean Baudrillard, Simulakrlar ve Simülasyon, Çev.: O. Adanır, 3. Baskı (Ankara: Doğu Batı, 2005).

Jean Baudrillard, Şeytana Satılan Ruh Ya da Kötülüğün Egemenliği, Çev.: O. Adanır (Ankara: Doğu Batı, 2005).

Madan Sarup, Post-Yapısalcılık ve Postmodernizm, Çev.: A. Güçlü (Ankara: Bilim ve Sanat, 2004).

Mevlüt Albayrak, "Dine Ya da Tanrıya Yeniden Yer Açma Çabası Olarak Postmodernizm ve Çoğulculuk", Tabula Rasa-Felsefe \& Teoloji, s. 11, Isparta, 2004.

Mevlüt Sarı, El-Mevarid (İstanbul: Bahar, 1982).

Michael York, "Postmodernity, Architecture, Society and Religion: A Heap of Broken Images or A Change of Heart", Postmodernity, Sociology and Religion (London: McMillan Press, 1966).

Mustafa Tekin, "Akıl/lar ve İslam Aklı", Diyanet Aylık Dergi, s. 297, Ankara, Eylül-2015.

Mustafa Tekin, Toplumun Vicdanı Olmak (İstanbul: Açılımkitap, 2015). 
Pamela Sue Anderson, "Postmodernizm ve Din", Postmodern Düşüncenin Eleştirel Sözlüğü, Ed.: S. Sim, Çev.: M. Erkan-A. Utku (Ankara: Ebabil, 2006).

Pauline Marie Rosenau, Post-Modernizm ve Toplumbilimleri-İçe-bakışlar, İçeri-dalışlar, İçeri-saldırılar, Çev.: T. Birkan, 2. Baskı (Ankara: Bilim ve Sanat, 2004).

Perry Anderson, Postmodernitenin Kökenleri, Çev.: E. Gen, 3. Baskı (İstanbul: İletişim, 2005).

Rainer Funk, Ben ve Biz-Postmodern İnsanın Psikanalizi, Çev.: Ç. Tanyeri, 2. Baskı (İstanbul: Yapı Kredi, 2009).

Sosyal Bilimler Sözlüğü, Ö. Demir-M. Acar (İstanbul: Ağaç, 1992).

Steven Best-Douglas Kellner, Postmodern Teori-Eleştirel Soruşturmalar, Çev.: M. Küçük (İstanbul: Ayrıntı, 1998).

Steven Lukes, Bireycilik, Çev.: İ. Serin (İstanbul: Ark, 1995).

Terry Eagleton, Postmodernizmin Yanılsamaları, Çev.: M. Küçük (İstanbul: Ayrint1, 1999). 


\title{
MİLEL VE NiHAL
}

inanç, kültür ve mitoloji araştırmaları dergisi

Cilt/Volume: 12 Sayı/Number: 2 Temmuz - Aralık / July - December 2015 ISSN: $1304-5482$

Bu dergi uluslararası EBSCO HOST Research Databases veri indeksi ve TÜBITAK-ULAKBİM Sosyal ve Beşeri Bilimler Veri Tabanı tarafından taranmaktadır.

\section{Sahibi / Owner}

Milel ve Nihal Eğitim, Kültür ve Düşünce Platformu Derneği adına Şinasi Gündüz

\author{
Yazı İşleri Sorumlusu / Legal Representative \\ Yasin Aktay
}

Editör / Editor

Şinasi Gündüz

Editör Yrd. / Co-Editor

Cengiz Batuk

Hakan Olgun

\section{Sayı Editörü / Editor of Issue \\ Mustafa Tekin}

Yayın Kurulu/ Editorial Board*

Alpaslan Açıkgenç, Ayaz Akkoyun, Yasin Aktay, Mahmut Aydın,

Cengiz Batuk, Şinasi Gündüz, İbrahim Kayan, Hakan Olgun, Necdet Subaşı,

Burhanettin Tatar

\section{Danışma Kurulu/Advisory Board*}

Baki Adam (Prof. Dr., AÜ); Mohd. Mumtaz Ali (Prof. International Islamic U. Malezya); Adnan Aslan (Prof.Dr., Süleyman Şah Ü.); Kemal Ataman (Doç.Dr., Uludağ Ü.); Mehmet Akif Aydın (Prof. Dr., Marmara Ü.); Yılmaz Can (Prof. Dr., OMÜ); Ahmet Çakır (Doç. Dr., OMÜ); Mehmet Çelik

(Prof. Dr., Celal Bayar Ü.); Waleck S. Dalpour (Prof. University of Maine at Farmington); İsmail

Engin (Dr., Berlin); Cemalettin Erdemci (Prof.Dr. YYÜ); Tahsin Görgün (Prof.Dr., 29

Mayıs Ü.) Ahmet Güç (Prof.Dr., Uludağ Ü.); Recep Gün (Doç. Dr., OMÜ); Ö. Faruk Harman

(Prof.Dr., Mar.Ü.); Erica C.D. Hunter (Dr., Cambridge U.); Mehmet Katar (Prof. Dr., A.Ü.);

Mahmut Kaya (Prof. Dr., İ.Ü.); Sadık Kılıç (Prof.Dr., Atatürk Ü.); Şevket Kotan (Y.Doç.Dr., İ.Ü.);

İlhan Kutluer (Prof.Dr., Mar. Ü.); George F. McLean (Prof. Catholic Univ., Washington DC); Ahmet Yaşar Ocak (Prof. Dr., Hacettepe Ü.); Jon Oplinger (Prof. University of Maine at Farmington); Ömer

Özsoy (Prof.Dr., Frankfurt U.); Roselie Helena de Souza Pereira (Mestre em

Filofia-USP; UNICAMP Brasil); Ekrem Sarıkçıŏlu (Prof.Dr., SDÜ); Hüseyin Sarığlu (Prof.Dr.,

İ̈); Bobby S. Sayyid (Dr. Leeds U.); Mustafa Sinanoğlu (Prof.Dr., 29 Mayıs Ü.); Mahfuz Söylemez

(Prof.Dr. İ̈); Necdet Subaşı (Y.Doç.Dr., DİB); Bülent Şenay (Prof.Dr., UÜ); İsmail Taşpınar

(Prof.Dr. Mar.Ü.); C. Sadık Yaran (Prof.Dr., OMÜ); Ali Murat Yel (Prof.Dr., Fatih Ü.); Hüseyin Yılmaz (Doç.Dr., YYÜ); Ali İhsan Yitik (Prof. Dr., DEÜ)

* Soyadına göre alfabetik sıra / In alphabetical order

Kapak ve Sayfa Tasarımı / Cover \& Page Design İnan Avc1

Baskı / Publication

Ladin Ofset - İstanbul, Nisan 2016

2.Mat. Sit. 3 NB 15 Topkapı İstanbul / İsmail Tüz 02125012418

Yönetim Yeri / Administration Place

Milel ve Nihal Eğitim, Kültür ve Düşünce Platformu Derneği

Fevzipaşa Cad. Şehit Mehmet Sarper Alus Sok. No: 5, K.: 3, Tel: (0212) 5339731 Fatih/İstanbul www.milelvenihal.org e-posta: dergi@milelvenihal.org

Milel ve Nihal yılda iki sayı olarak altı ayda bir yayımlanan uluslararası hakemli bir dergidir. Milel ve Nihal'de yayımlanan yazıların bilimsel ve hukuki sorumluluğu yazarlarına aittir. Yayım dili Türkçe ve İngilizce'dir. Yayımlanan yazıların bütün yayın hakları Milel ve Nihal'e ait olup, yayıncının izni olmadan kısmen veya tamamen basılamaz, çoğaltılamaz ve elektronik ortama taşınamaz. Yazıların yayımlanıp yayımlanmamasından yayın kurulu sorumludur. 


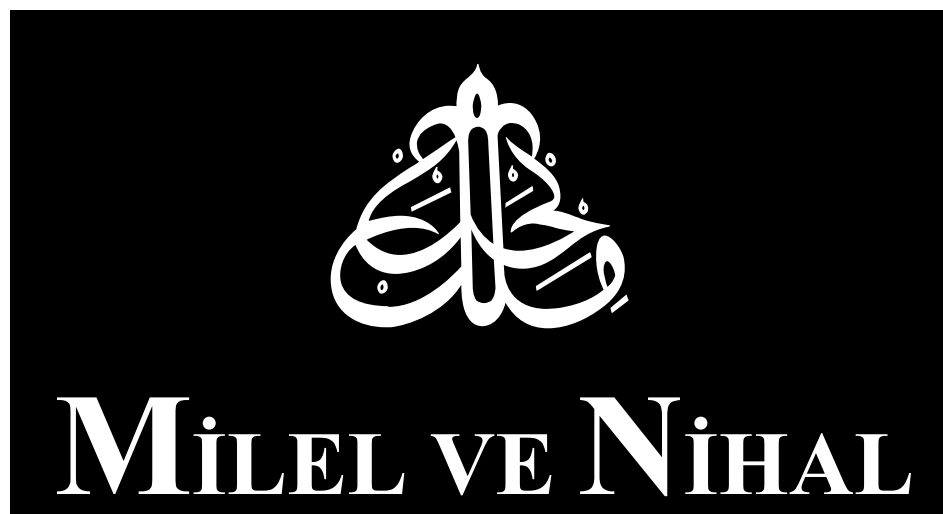

inanç, kültür ve mitoloji araştırmaları derģisi

ISSN: 1304-5482

DIN VE POSTMODERNIZMM

Cilt/Volume: 12 Sayı/Number: 2

Temmuz - Aralık / July - December 2015 
